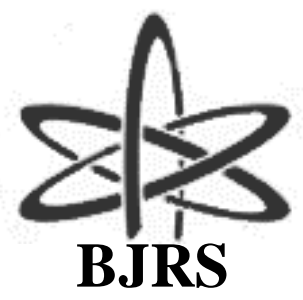
BRAZILIAN JOURNAL
$\mathrm{OF}$
RADIATION SCIENCES
07-03 (2019) 01-13

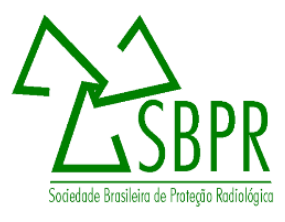

\title{
Radiation hazard indices in the application of phosphogypsum mixtures as a building material: proposal for a Brazilian regulation
}

\author{
Máduar $^{\mathrm{a}}$ M.F, Mazzilli ${ }^{\mathrm{a}}$ B.P., Nisti ${ }^{\mathrm{a}}$ M.B. \\ ${ }^{a}$ Instituto de Pesquisas Energéticas e Nucleares, Av. Professor Lineu Prestes 2242, 05508-000 São Paulo, SP, Brazil \\ mmaduar@ipen.br
}

\begin{abstract}
Phosphogypsum (PG), a by-product from the phosphoric acid industry, is being worldwide stockpiled, posing environmental problems. Viability of the PG safe re-use in civil construction has been studied, as PG can contain natural radionuclides in significant concentrations. We propose a policy for using PG as a building material, limiting the total concentration of ${ }^{226}$ Ra plus ${ }^{228}$ Ra by mixing PG with natural gypsum. It was concluded that PG from the largest Brazilian deposits could be used without any dilution, when the sum of the activity concentrations of ${ }^{226} \mathrm{Ra}$ and ${ }^{228} \mathrm{Ra}$ does not exceed $150 \mathrm{~Bq} \mathrm{~kg}^{-1}$. For higher values, the approach is to mix PG with increasing amounts of natural gypsum, so that the final concentration does not exceed $1000 \mathrm{~Bq} \mathrm{~kg}^{-1}$. We show that PG re-use in such a way is feasible in terms of radiological protection and recommended to minimize PG piles environmental impact.
\end{abstract}

Keywords: phosphogypsum, NORM, radiation hazard index. 


\section{INTRODUCTION}

Naturally occurring radionuclides are present in several natural resources. High concentrations of these radionuclides are found in geological materials, mainly igneous rocks and some ores. Human activities that exploit such resources can lead to an increase in the concentration of these radionuclides, giving rise to materials that are known as "Naturally Occurring Radioactive Material" - NORM.

A typical example is the mining and processing of phosphate rock to produce phosphoric acid, phosphate fertilizers and animal feed. Use of sulfuric acid in the process generates calcium sulfate precipitate $(\mathrm{CaSO} 4 \cdot n \mathrm{H} 2 \mathrm{O})$, known as phosphogypsum, which is considered a residue due to its content of impurities. In terms of rounded figures, the production of 1 ton of phosphate results in the generation of $4-5$ ton of phosphogypsum. In Brazil, the main producers of phosphate fertilizers are responsible for the production of approximately 12 million tons of PG per year, which is stored in stacks, posing major environmental concern.

According to the document of International Atomic Energy Agency TECDOC-1712, "Management of NORM Residues" [1], the IAEA currently establishes in its BSS (Basic Safety Standards) [4] that the general criterion for exemption of control is met when the activity concentration of all radionuclides in the ${ }^{238} \mathrm{U}$ and ${ }^{232} \mathrm{Th}$ decay series in the residue is less than or equal to $1 \mathrm{~Bq} \mathrm{~g}^{-1}$ and ${ }^{40} \mathrm{~K}$ activity concentration is less than or equal to $10 \mathrm{~Bq} \mathrm{~g}^{-1}$.

However, in the case of industrial plants, due to the large amounts of material usually involved, it is more appropriated for such activities to be subject to regulatory control, even in the case the criterion for exemption is met, in the following way: if every material in the process has activity concentrations below than the activity concentration criteria, the activity is not regarded as a practice and requirements for existing exposure apply; otherwise, the activity is regarded as a practice and requirements for planned exposure apply [1].

The same document states that there is an overall trend worldwide towards greater recycling of NORM residues and their use as by-products. This is being driven by a growing recognition that the amounts of NORM disposed of as waste need to be minimized and by sustainability considerations such as concern for the depletion of non-renewable resources and the environmental protection 
legislation increasingly restrictive. Some countries are now incorporating, in their regulatory systems, recycling or re-use of NORM waste [1,2].

The new Euratom document Basic Safety Standards (EU-BSS) [3] contains requirements for industrial sectors involving Naturally Occurring Radioactive Materials (NORMs) and the use of specific residues from the considered industrial sectors in building materials. The EU-BSS is expected to be transposed in national and regional legislations for all the member states of the EU. Worldwide, the safe use of NORM residue is also becoming increasingly important; the recent Radiation Protection and Safety of Radiation Sources: International Basic Safety Standards [4] also emphasizes this new approach.

In this work, a case study is performed, using the physical parameters of Brazilian phosphogypsum from different origins, already characterized in previous papers $[5,6,7]$. The data are applied to well established methodologies for evaluating the radiation hazard indices. This work intends to contribute to the national regulatory authority in the definition of constraints for using phosphogypsum as construction material.

\section{RADIONUCLIDE CONTENTS IN BUILDING MATERIALS}

The main concern related to the radioactivity in regular building materials is the gamma exposure arising from the ${ }^{238} \mathrm{U}$ and ${ }^{232} \mathrm{Th}$ decay series, which can cause health hazards in dwellers. Furthermore, radionuclide ${ }^{226} \mathrm{Ra}$ from the ${ }^{238} \mathrm{U}$ series, which decays to ${ }^{222} \mathrm{Rn}$ through an alpha particle emission, is one of the most important radionuclides from the point of view of radiation protection $[2,8,10,11,18]$.

The main health hazard associated with $\mathrm{Rn}$ is due to its short-lived alpha emitter decay products, which can cause damage to the lungs after chronic exposure. Therefore, its safe utilization requires an evaluation of the radiological impact in dwellers, which comprises the evaluation of internal exposure due to radon inhalation and external exposure due to gamma radiation.

The internal exposure indoors depends mainly on the activity concentration of ${ }^{226} \mathrm{Ra}$ and ${ }^{228} \mathrm{Ra}$ in the construction material and the radon exhalation rate, which can be determined by using theoretical models $[8,9]$, measured experimentally or by employing an approach combining both 
modeling and experimental measurements indoors [10]. The exhalation rate is defined as the amount of activity released per unit surface area per unit time from the material. It depends on the ${ }^{226} \mathrm{Ra}$ content of the material, emanation factor, gas diffusion coefficient in the material, porosity and density of the material.

To limit the radiation exposure, the criteria commonly employed is to define different constraints for the radiation indices, according to the over-all amount of material to be used as building material. Specifically, different acceptable indices are adopted whether the intended usage is superficial usage or bulk usage [11].

Materials like ceramic tiles [12] and granites [13, 14] are used mainly in superficial coating. Such usage enhances the radon exhalation, since the distance for the radon to reach the outer surface is shorter [15].

The bulk usage of building materials tends to decrease the ratio between the ${ }^{226} \mathrm{Ra}$ concentration and the radon exhalation, since the gas can be trapped in the building material. In this case, the radon decays within the building structure, thus increasing the concentration of the short-lived gamma-ray emitting decay products [15]. Typical usage of materials like concrete, cement and natural gypsum falls in this category.

\section{RADIONUCLIDE CONTENTS IN PHOSPHOGYPSUM}

The characterization of radionuclides in the Brazilian phosphate fertilizer industry shows that radium isotopes, ${ }^{210} \mathrm{~Pb},{ }^{210} \mathrm{Po}$ and thorium isotopes fractionate preferentially to the phosphogypsum, where percentages (to phosphate rock) of $90 \%$ (radium isotopes), $100 \%\left({ }^{210} \mathrm{~Pb}\right), 78 \%\left({ }^{210} \mathrm{Po}\right)$ and $80 \%$ (thorium isotopes) are found. The uranium isotopes are predominantly incorporated in phosphoric acid as uranyl phosphate, sulphate or fluoride complexes [6]. Several papers were published concerning the characterization of radionuclides present in Brazilian PG [5, 6, 7]. The activity concentrations of the natural radionuclides in the PG of the three main Brazilian fertilizer producers from the latter references, named here as " $\mathrm{A}$ ", "B" and "C", are summarized in Table 1. 
Table 1: Phosphogypsum activity concentration (ranges in $\mathrm{Bq} \mathrm{kg}^{-1}$ ) in $\mathrm{PG}$ from main producers in Brazil.

\begin{tabular}{cccc}
\hline Producer & A & B & C \\
\hline Location & Cubatão & Uberaba & Cubatão \\
\hline${ }^{238} \mathrm{U}$ & $42-53$ & $23-50$ & $40-58$ \\
${ }^{226} \mathrm{Ra}$ & $550-940$ & $122-236$ & $280-434$ \\
${ }^{210} \mathrm{~Pb}$ & $834-1163$ & $136-228$ & $316-378$ \\
${ }^{232} \mathrm{Th}$ & $189-257$ & $60-103$ & $172-243$ \\
${ }^{228} \mathrm{Ra}$ & $210-273$ & $124-179$ & $191-247$ \\
\hline
\end{tabular}

Considering the huge amount of PG continuously stacked and its potential threaten to the environment [16, 17], it is an important issue to evaluate possibilities of re-using such residue to minimize its environmental impact. Considerations about the viability of the safe reuse of this material have been raised, among them its potential use as building material.

In 2013, the Brazilian regulatory agency on nuclear energy has established a working group with the objective of evaluating the viability of defining a policy for using phosphogypsum as a building material [18]. In this context, an approach limiting the concentration of PG to be mixed with gypsum, based on ${ }^{226} \mathrm{Ra}$ and ${ }^{228} \mathrm{Ra}$ concentrations found in $\mathrm{PG}$, according to the forecast hazard indices resulting by using the mixture was suggested.

\section{METHODS}

\subsection{Methodology for radiation hazard indices evaluation}

In Brazil, PG has been used, on a small scale, as construction material, mainly as bricks and plaster board, although the specific requirements from the regulator were not published yet. Regular plasterboard specifications for use as building material are regulated in Brazil by the relevant national technical standard [19]. For gypsum bricks, there are yet few producers in Brazil; the apparent density range of the final product is 1.65 to $1.75 \mathrm{~g} \mathrm{~cm}^{-3}$.

The estimated radiation dose to which dwellers are exposed within a building, due to the existing radionuclides in the wall, is the result of the contribution from: 
- the external dose due to gamma radiation emitted by ${ }^{40} \mathrm{~K}$ and the radionuclides ${ }^{226} \mathrm{Ra},{ }^{228} \mathrm{Ra}$ and its decay products, present in the walls of the building;

- the internal dose due to inhalation of ${ }^{222} \mathrm{Rn}$ exhaled to the internal environment of the building, originating from the decay of ${ }^{226} \mathrm{Ra}$ contained in the walls.

In the literature, several expressions were published for estimation of the dose, resulting in a hazard index, used as a criterion to ensure that the effective dose does not exceed the limiting annual dose [20, 21]. As far as in 1992, a national standard, ÖNORM S 5200, was adopted in Austria and established the criterion expressed in Equation (1) [21]:

$$
\frac{C\left({ }^{40} K\right)}{9620}+\frac{C\left({ }^{226} R a\right)}{740}(1+0.1 \varepsilon \rho d)+\frac{C\left({ }^{232} T h\right)}{520} \leq 1
$$

where $C(X)$ is the concentration of radionuclide $X$ in the building material $\left(\mathrm{Bq} \mathrm{kg}^{-1}\right), \varepsilon$ is the radon exhalation fraction from the internal walls, $\rho$ is the density $\left(\mathrm{kg} \mathrm{m}^{-3}\right)$, and $d$ is the thickness of the walls (m).

Equation (1) incorporates the following assumptions to include the radon contribution: ratio between superficial area and internal volume is $2 \mathrm{~m}^{-1}$; activity concentration of radon in air is $37 \mathrm{~Bq} \mathrm{~m}^{-3}$, with a mean equilibrium factor of 0.5 , resulting in an effective dose of about $2 \mathrm{mSv} \mathrm{y}^{-1}$, value that was then the limiting dose for the public. This formulation assumes annual average rate of ventilation within the dwelling compartments equal to $0.7 \mathrm{~h}^{-1}$ [21].

If the building material has a product $(\rho d)$ less than $250 \mathrm{~kg} \mathrm{~m}^{-2}$, the term $(1+0.1 \varepsilon \rho d)$ in Equation (1) can be replaced [21] by the term

$$
(1+25 \varepsilon)
$$

In the present study, a modified hazard index with respect to the one previously proposed [21] is employed to obtain a limiting dose of $1 \mathrm{mSv} \mathrm{y}^{-1}$, rather than $2 \mathrm{mSv} \mathrm{y}^{-1}$, to comply with the current international recommendations. This is achieved simply by dividing by 2 the denominators of the terms, resulting in the Equation (3):

$$
\frac{C\left({ }^{40} K\right)}{4810}+\frac{C\left({ }^{226} R a\right)}{370}(1+0.1 \varepsilon \rho d)+\frac{C\left({ }^{232} T h\right)}{260} \leq 1
$$


where the quantities are defined in the same way as Equation (1).

In the present proposal, the adoption of this formulation is justified by the fact that the contribution for the dose arising from the ${ }^{222} \mathrm{Rn}$ exhaled from the building material due to its ${ }^{226} \mathrm{Ra}$ content is explicitly included.

\subsection{Experimental data of gypsum bricks and boards}

In this work, the following values were adopted in Equations (2) and (3):

$C(X)$ : Highest concentration values for each application range of the mixture;

$\varepsilon=0.1$ : maximum realistic value corresponding to a $10 \%$ emanation coefficient, as reported in previous works $[21,22]$.

$d=0.1 \mathrm{~m}$ : This value is above of the maximum admissible thickness for gypsum plates, according to Brazilian regulation [19], which is $0.015 \mathrm{~m}$. Such value is equal to the width of the only gypsum brick model currently produced in Brazil, compliant to the applicable engineering regulation [23], as informed by the producer.

$\rho=1750 \mathrm{~kg} \mathrm{~m}^{-3}$ : Value corresponding to the greatest density experimentally found for gypsum bricks [24], and is also above the maximum density allowed for plasterboard, which is $933 \mathrm{~kg} \mathrm{~m}^{-3}$ [25]. In the present case, the product $(\rho d)$ is $1750 \mathrm{~kg} \mathrm{~m}^{-3} \times 0.10 \mathrm{~m}=175 \mathrm{~kg} \mathrm{~m}^{-2}$, value below $250 \mathrm{~kg} \mathrm{~m}^{-2}$, therefore Equation (2) is applicable.

\section{RESULTS AND DISCUSSION}

To comply with Equations (2) and (3), several hypothetical mixtures of phosphogypsum and mineral gypsum were assumed, varying the phosphogypsum percentages $p$ in the mixtures. For each $p$ value, the activity concentrations of ${ }^{226} \mathrm{Ra}$ and ${ }^{228} \mathrm{Ra}$ in the mixture, $C(\mathrm{mix})$, were calculated from the activity concentrations in $\mathrm{PG}, C(P G)$, and in natural gypsum, $C($ gyp $)$, by using Equation (4):

$$
C(\operatorname{mix})=p \cdot C(P G)+(1-p) \cdot C(g y p)
$$


The hazard indices were evaluated for the following ${ }^{226} \mathrm{Ra}$ and ${ }^{228} \mathrm{Ra}$ concentrations assumed for the phosphogypsum, as follows:

- ${ }^{226}$ Ra: 50, 100, 150, 200, 300, 400, 600, 800, and1000 Bq kg ${ }^{-1}$

- ${ }^{228} \mathrm{Ra}: 50,100,200,300$, and $400 \mathrm{~Bq} \mathrm{~kg}^{-1}$

In adopting such values, the criterion of fixing the upper limits of each range in values above of the typical experimental values from each main PG stockpiled in Brazil was employed, to allow a well-defined classification of each deposit. The content of radionuclides in the main Brazilian producers was used as a database to define the ranges of radionuclide concentrations in this study [26].

For mineral gypsum, the following values were adopted, based on experimental determinations [24]: $2.8 \mathrm{~Bq} \mathrm{~kg}^{-1}$ for ${ }^{226} \mathrm{Ra}$, and $1.7 \mathrm{~Bq} \mathrm{~kg}^{-1}$ for ${ }^{228} \mathrm{Ra}$. For the ${ }^{40} \mathrm{~K}$ concentrations, $50 \mathrm{~Bq} \mathrm{~kg}^{-1}$ was adopted for all PG/gypsum mixtures, as no analyzed PG in Brazil presented concentration above this value [27]. Equations $(2,3,4)$ were applied to PG/gypsum compositions, with several PG percentages in the $0 \%-100 \%$ range, by increments of $5 \%$.

The allowable PG percentage adopted, for each ${ }^{226} \mathrm{Ra}$ and ${ }^{228} \mathrm{Ra}$ concentrations pair, was the highest possible so that the resulting effective dose was below $1 \mathrm{mSv}$ for each expression employed. Table 2 summarizes such percentages for upper amounts of ${ }^{226} \mathrm{Ra}$ and ${ }^{228} \mathrm{Ra}$ in the PG intended to be mixed for using as a building material. 
Table 2: Maximum allowed PG percentage mixed with natural gypsum as a function of ${ }^{226} \mathrm{Ra}$ and ${ }^{228} \mathrm{Ra}$ activity concentrations in PG.

\begin{tabular}{cccccc}
\hline & \multicolumn{6}{c}{ Concentration of ${ }^{\mathbf{2 2 8}} \mathbf{R a}\left(\mathbf{B q} \mathbf{~ k g}^{\mathbf{- 1}}\right)$} \\
\cline { 2 - 6 } Concentration of $\left.{ }^{\mathbf{2 2 6}} \mathbf{R a}(\mathbf{B q ~ k g})^{-1}\right)$ & $\mathbf{4 0 0}$ & $\mathbf{3 0 0}$ & $\mathbf{2 0 0}$ & $\mathbf{1 0 0}$ & $\mathbf{5 0}$ \\
\hline 50 & $50 \%$ & $65 \%$ & $85 \%$ & $100 \%$ & $100 \%$ \\
100 & $45 \%$ & $50 \%$ & $60 \%$ & $85 \%$ & $100 \%$ \\
150 & $35 \%$ & $40 \%$ & $50 \%$ & $65 \%$ & $75 \%$ \\
200 & $30 \%$ & $35 \%$ & $40 \%$ & $50 \%$ & $55 \%$ \\
300 & $25 \%$ & $30 \%$ & $30 \%$ & $35 \%$ & $40 \%$ \\
400 & $20 \%$ & $25 \%$ & $25 \%$ & $25 \%$ & $30 \%$ \\
600 & $15 \%$ & $15 \%$ & $15 \%$ & $20 \%$ & $20 \%$ \\
800 & $15 \%$ & $15 \%$ & $15 \%$ & $15 \%$ & $15 \%$ \\
1000 & $10 \%$ & $10 \%$ & $10 \%$ & $10 \%$ & $10 \%$ \\
\hline
\end{tabular}

It must be stressed that the only way that the proposed mechanism could operate is regarding it as a practice subject to clearance by the Brazilian regulatory body. To guarantee that the proposed standard is met, it would be necessary to establish control procedures including regular PG sampling programs and formal notifications from the producers in order to allow the PG enter the public domain, in an approach analog to that already established by the Brazilian Regulatory body for the control of using phosphogypsum in agriculture and cement industry [29].

\section{CONCLUSION}

It was concluded that PG from the largest Brazilian deposits could be used without any dilution, when the summation of the activity concentrations of ${ }^{226} \mathrm{Ra}$ and ${ }^{228} \mathrm{Ra}$ does not exceed $150 \mathrm{~Bq} \mathrm{~kg}^{-1}$. For activity concentrations higher than $150 \mathrm{~Bq} \mathrm{~kg}^{-1}$, the approach is to mix PG with increasing amounts of natural gypsum, so that the final concentration does not exceed $1000 \mathrm{~Bq} \mathrm{~kg}^{-1}$.

The proposal of using PG mixed with other materials, in order to dilute the radioactive content of the former, is consonant with the interpretation expressed in the IAEA-TECDOC-1712 [1], 
which reinforces the need for considering and applying options, adequate for local conditions, for the re-use of industrial by-products, contributing to solve the issue of PG disposal as waste and to save a non-renewable natural resource.

Ideally, new materials intended for bulk usage and in large amounts, as is the case of civil construction, should be designed by using uniquely residues from human activities. Materials like PET and rubber from outdoor deposits, for example, have been considered for including in the formulation of new building materials. However, the necessary tests to guarantee the performance and safety for general application usually take years to complete.

In this context, dilution remains an option to be considered. Specifically, according to reference [1], dilution of PG has even been incorporated into The Netherlands' regulatory system.

The proposal for employing phosphogypsum mixed with natural gypsum as a building material, presented in this paper, if adopted nationwide, could have a significant positive impact, by contributing to reduce the huge amounts of phosphogypsum disposed and saving non-renewable resources like mineral gypsum.

\section{ACKNOWLEDGMENT}

The authors are grateful to all the members of the Working Group established by Ordinance DRS/CNEN n. 1, Jan. 3, 2013, of the Brazilian National Nuclear Energy Commission, to propose regulations for use of phosphogypsum as construction material. One of the authors has support of Conselho Nacional de Desenvolvimento Científico e Tecnológico, CNPq, grant 300835/95-7.

\section{REFERENCES}

[1] INTERNATIONAL ATOMIC ENERGY AGENCY (2013). Management of NORM Residues (IAEA-TECDOC-1712), Vienna.

[2] KOVLER, K. (2003). Radiological constraints of using building materials and industrial byproducts in construction, Construction and Building Materials, 23(1), 246-253. 
[3] EUROPEAN COMMISSION. Laying Down Basic Safety Standards for Protection Against the Dangers Arising From Exposure To Ionising Radiation. World Health, 0254:126, 2013.

[4] INTERNATIONAL ATOMIC ENERGY AGENCY (2004). Radiation Protection and Safety of Radiation Sources: International Basic Safety Standards. General Safety Requirements Part 3. International Atomic Energy Agency Vienna, 3:436.

[5] MAZZILli, B. P., PALMiRO, V., SAUEIA, C. H. R. AND Nisti, M. B. (2000). Radiochemical characterization of Brazilian phosphogypsum. Journal of Environmental Radioactivity, 49(1), 113-122.

[6] SAUEIA, C. H. R. AND MAZZILLI, B. P. (2006). Distribution of natural radionuclides in the production and use of phosphate fertilizers in Brazil. Journal of Environmental Radioactivity, 89(3), 229-239.

[7] SAUEIA, C. H. R., MAZZILli, B. P. AND TADDEI, M. H. T. (2009). Sequential radioanalytical method for the determination of $U$ and $T h$ isotopes, ${ }^{226} \mathrm{Ra}$ and ${ }^{210} \mathrm{Po}$ using alpha spectrometry in samples of the Brazilian phosphate industry. Journal of Radioanalytical and Nuclear Chemistry, 281(2), 201-204.

[8] MÁdUAR, M. F. AND HIROMOTO, G. (2004). Evaluation of indoor gamma radiation in dwellings. Radiation Protection Dosimetry, 111(2), 221-228.

[9] MANIĆ, V., MANIĆ, G., NIKEZIC, D. AND KRSTIC, D. (2012). Calculation of dose rate conversion factors for ${ }^{238} \mathrm{U},{ }^{232} \mathrm{Th}$ and ${ }^{40} \mathrm{~K}$ in concrete structures of various dimensions, with application to Niš, Serbia. Radiation Protection Dosimetry, 152, 361-368.

[10]MÁDUAR, M. F., CAMPOS, M. P., MAZZILli, B. P. AND VILlAVERDE, F. L. (2011). Assessment of external gamma exposure and radon levels in a dwelling constructed with phosphogypsum plates. Journal of Hazardous Materials, 190, 1063-1067.

[11]EUROPEAN COMMISSION. Radiological protection principles concerning the natural radioactivity of buildings materials, volume 112 (1999).

[12]RIGHI, S. GUERRA, R. JEYAPANDIAN, M. VERITÀ, S. AND ALBERTAZZI, A. (2009). Natural radioactivity in Italian ceramic tiles. Radioprotection, 44(5), 413-419.

[13]FERREIRA, A. O. AND PECEQUILO, B. R. S. (2011). Natural radioactivity assessment by gamma spectrometry in some commercially-used granites from Paraná State, Brazil: Preliminary results. Radioprotection, 46(6), 43-47. 
[14]LLOPE, W. J. (2011). Activity concentrations and dose rates from decorative granite countertops. Journal of Environmental Radioactivity, 102(6), 620-629.

[15]FERREIRA, A. O, PECEQUILO, B. R. S. AND AQUINO, R. R. (2011). Application of a Sealed Can Technique and CR-39 detectors for measuring radon emanation from undamaged granitic ornamental building materials. Radioprotection, 46(6), 49-54.

[16]SILVA, P. S. C., MAZZILli, B. P. AND FÁVARO, D. I. T. (2006). Distribution of radionuclides and elements in Cubatão river sediments. Journal of Radioanalytical and Nuclear Chemistry, 269(3), 767-771.

[17] OliveirA, S. M. B., Silva, P. S. C., MAZZILli, B. P., FÁVARO, D. I. T., SAUEIA, C. H. (2007). Rare earth elements as tracers of sediment contamination by phosphogypsum in the Santos estuary, southern Brazil. Applied Geochemistry, 22, 837-850.

[18]CAMPOS, M. P., COSTA, L. J. P., NISTI, M. B. AND MAZZILLI, B. P. (2017). Phosphogypsum recycling in the building materials industry: assessment of the radon exhalation rate. Journal of Environmental Radioactivity, 172, 232-236.

[19]ASSOCIAÇÃO BRASILEIRA DE NORMAS TÉCNICAS. NBR 14717: Chapa de gesso acartonado - Determinação das características físicas, 2001.

[20] KARPOV, V. I. AND KRISIUK, E. M. (1990). Estimation of indoor gamma dose rate. Health Physics, 39, 819-821.

[21]STEGER, F., KUNSCH, B. AND BUCHNER, I. (1992). ÖNORM S 5200: radioactivity in building materials (A standard in Austria to limit natural radioactivity in building materials). Radiation Protection Dosimetry, 45(1-4), 721-722.

[22]BOSSEW, P. (2003). The radon emanation power of building materials, soils and rocks. Applied Radiation and Isotopes, 59(5-6), 389-392.

[23] ASSOCIAÇÃO BRASILEIRA DE NORMAS TÉCNICAS. NBR 14715-2 - Chapas de gesso para drywall - Parte 2: determinação das características físicas, 2010.

[24]COSTA, L. J. P. Estudo da exalação de radônio em placas e tijolos de fosfogesso de diferentes procedências. Master thesis, Instituto de Pesquisas Energéticas e Nucleares, 2011.

[25] ASSOCIAÇÃO BRASILEIRA DE NORMAS TÉCNICAS. NBR 14715-1 - Chapas de gesso para drywall - Parte 1: requisitos, 2010. 
[26]SANTOS, A. J. G., SilvA, P. S. C., MAZZILli, B. P. AND FÁVARO, D. I. T. (2006). Radiological characterisation of disposed phosphogypsum in Brazil: Evaluation of the occupational exposure and environmental impact. Radiation Protection Dosimetry, 121(2), 179-185.

[27]NISTI, M. B., CAMPOS, M. P. AND MAZZILLI, B. P. (2014). Natural radionuclides content and radon exhalation rate from Brazilian phosphogypsum piles. Journal of Radioanalytical and Nuclear Chemistry, 299(1), 261-264.

[28]CAMPOS, M. P. AND PECEQUILO, B. R. S. (2004). Dosimetric assessment from ${ }^{212} \mathrm{~Pb}$ inhalation at a thorium purification plant. Radiation Protection Dosimetry, 111(3), 323-326.

[29]COMISSÃO NACIONAL DE ENERGIA NUCLEAR (2014). Uso do fosfogesso na agricultura e na indústria cimenteira. Resolução CNEN 179/14. Brasil, 2014. 